\title{
Plant Exchange Networks and their Importance in Mbyá-Guarani Medicine in Southern Brazil
}

Julian Henrique Carlotto de Andrade

UFSC

José Rodrigues

Tekoá Nhuu Porã

André Benites

Tekoa Ka'aguy Porã

Cornélio Benites

Tekoa Jatai'ty

Arlindo Acosta

Tekoa Jatai'ty

Marcelina Benites

Tekoa Jatai'ty

Cocelina Benites

Tekoa Jatai'ty

Ilda Gomes

Tekoa Jatai'ty

Jaime Valdir da Silva

Tekoa Jatai'ty

Eunice Antunes

Tekoa Itaty

Elisete Antunes

Tekoa Yakã Porã

José Martins

Tekoa Itaty

Daniel Martins Timóteo

Tekoa Yyn Moroty Vhera

Santiago Franco

Tekoa Ywy Poty

José Cirilo Pires Morinico

Tekoa Anhetengua

Fernanda Ribeiro da Silva

Universidade Federal de Santa Catarina

Natalia Hanazaki ( $\square$ hanazaki@gmail.com ) 
Universidade Federal de Santa Catarina https://orcid.org/0000-0002-7876-6044

\section{Research}

Keywords: Ethnobotany, Mbyá-Guarani, Exchange networks, Traditional medicine

Posted Date: December 30th, 2020

DOI: https://doi.org/10.21203/rs.3.rs-136023/v1

License: (c) (1) This work is licensed under a Creative Commons Attribution 4.0 International License. Read Full License 


\section{Abstract}

Background: Experts in the Atlantic Forest, the Guarani people have the habit of transporting and exchanging plants due to their mobility throughout the territory. Historically, this habit contributed to the species composition and diversification among different phytophysiognomies that comprise the Atlantic Forest. Medicine and spirituality are traits that stand out within the Guarani culture, which is based on a holistic understanding of physical and spiritual well-being for the person's health. To achieve this balance, they use a range of native and adapted plant species. Our goal is to understand some of the Guarani contributions to the cultural landscape in the Atlantic Forest. We also investigate whether kinship relations can facilite plant exchanges used in medicinal or mystical contexts between Guarani people.

Methods: We conducted semi-structured interviews with key persons asking about the importance of forest environments for Guarani health and about visits to other Guarani villages and plants exchanged.

Results: We visited seven Guarani Indigenous Territories in south Brazil, and with the participation of 12 respondents, we registered 27 species that were exchanged through different phytophysiognomies in the Atlantic Forest. These results show an intense movement of plants currently occurring between villages and the importance of these movements for both individual health and the integrity of the environments in which the Guarani villages are inserted.

Conclusions: We observed a search for the recomposition of traditional species in the Guarani medical system, and we highlight the fundamental role of Guarani management in the conservation of the southern Atlantic Forest in indigenous territories.

\section{Background}

Since immemorial times, the use of medicinal plants is the best known and most practiced way to treat and relieve diseases among local communities, such as indigenous peoples $(1,2)$. In Brazil, there are among 305 indigenous peoples, and the Guarani people are one of the most populous of them, with approximately 85,000 people (3). The Guarani are currently divided into three main groups: Kaiowá, Nhandevá/Chiripá and Mbyá, the latter corresponding to the majority of the Guarani population living near the Brazilian coast $(4,5)$.

Historically, the Guarani occupy the lowland region of South America, mainly in the Paraguay, Paraná, and Uruguay River basins, and the southern Atlantic coast of Brazil, ranging from the states of São Paulo to Rio Grande do Sul, where they are currently distributed. The Guarani also inhabit the Brazilian states of Mato Grosso do Sul, Espírito Santo, Rio de Janeiro, Tocantins, and Pará. With the exception of these last two states, the Guarani territories are within the Atlantic Forest biome, which is a fundamental element for the Guarani way of being, the nhande reko. Along many centuries of occupation of this biome, the Guarani people established deep relations with the forest. The Guarani presence in the region is estimated, from archaeological records, to be at least ca. 2,000 years, depending on location $(6,7,8,9$, 
10). Unfortunately, the demarcation of their territories is still one of the major challenges faced by the Guarani, despite being the native inhabitants of the region.

Ethnographic research about the Guarani people includes studies on their sociocultural identity, both historical and contemporaneous migratory processes, and botanical, agroecological, and ecological knowledge that report their vast knowledge of the native flora $(11,12,13,14,15)$. Being descendants of the Tupi cultural matrix, the Guarani continued the agroforestry systems developed in the Amazon, in their migration and expansion movements and in a process of ecological adaptation, seeking fertile areas in the subtropical forests that best fit their lifestyle $(7,10,16$; see also Brochado (17), Noelli $(13,18)$, and Rogge (19)). Thus, linked to their plant knowledge, another culturally striking feature that accompanied the Guarani throughout their history is their mobility.

The Guarani are dynamic people. Visits and migrations between villages are part of their way of life. Visits favor exchanges and are encouraged by factors such as strengthening family ties, bringing health and happiness, and by economic-environmental or cosmological aspects $(20,21,22)$. Many indigenous peoples have a systemic and holistic perception of the world (23), with no boundaries between humans (society) and nature (ecosystem) (24). In Guarani cosmoecology, moving through the traditional territory (Yvy Rupa) is part of their well-being, or teko porã, maintaining joy and health (25). The principle of reciprocity, or mborayu, is fundamental for the Mbyá-Guarani (20): guided by kinship, economic activities, and other aspects of social life such as residence, religious life, alliances and leaderships, this principle assumes varied features that are related to their own mobility (14).

Thus, Guarani mobility is also related to the transportation and exchange of plants $(1,5,16,26,27,28)$. This mobility contributes to the maintenance of food plants and of the Guarani pharmacopoeia $(5,13$, 27 ) and can contribute to the formation of cultural landscapes $(13,18,29,30,31)$ within the Atlantic Forest. The Atlantic Forest inhabited by the Guarani includes different phytophysiognomies, including dense ombrophylous forest, mixed ombrophylous forest, seasonal semideciduous forest and deciduous forest, as well as transition areas between these phytophysiognomies and areas in different successional stages $(10,21,27,32)$. The circulation and transport of propagules between different villages may result in exchanges of plants of different phytophysiognomies.

According to Votre et al. (32), the success of Guarani occupations in forest environments is due to their botanical and ecological knowledge. A database of useful species of the flora for the Guarani in Santa Catarina (southern Brazil), Argentina, and Paraguay, organized by Pereira, Noelli, Campos, Santos, Zocche (28) and complemented by Votre et al. (32), registered the traditional use of 956 species belonging to 131 botanical families. Noelli (18) surveyed plants for therapeutic purposes among Guarani communities of Paraguay, Mato Grosso do Sul, Argentina, and Rio Grande do Sul and listed 151 species from an inventory of more than 800 plants. Additionally, Crovetto (33) cited the use of 438 plants among Mbyá in northwestern Argentina, most for medicinal purposes.

The circulation and transport of plants and seeds and the associated transmission of knowledge can be studied through social network analysis $(34,35,36,37)$. These studies highlight variations in traditional 
ecological knowledge related to characteristics such as age, gender, kinship, education, place of residence, level of acculturation, social position and level of integration in the economic market. For example, in two Tsimane villages in the Bolivian Amazon, Díaz-Reviriego et al. (34) found high rates of diversity in exchange networks of home-grown crops, influenced by women and kinship ties. Similarly, Lope-Alzina (37) observed that among members of a Yucatec-Maya community in Mexico, home gardens are the main source of exchanged plants. Despite strong market share, gifts remain the predominant form of exchange, with most gifts coming from home gardens and with most exchanges taking place among women in kinship networks (37). Routes of knowledge transmission about medicinal plants among the Yucatec-Maya in Mexico showed that the individual knowledge of medicinal plants is positively associated with the position in the network of exchanges of knowledge about herbal medicines (36). In Africa, Europe, Latin America and Oceania, Coomes et al. (38) showed that farmers with leading social positions and strong ethnobotanical knowledge were expected to be the main seed suppliers in seed networks.

The aim of this study was to investigate the current exchanges of plants between Guarani villages, contributing to the formation of cultural landscapes $(13,18,29,31)$, which may have occurred since preColumbian times (30). Our main hypothesis is that villages with stronger family ties exchange more propagules than others. The specific objectives were (1) to describe the exchange networks of plant propagules of medicinal and mystical or religious importance between Guarani villages in southern Brazil and (2) to discuss the importance of plants and environments for eco-cultural Guarani health. We focus on seeking plants used and interchanged for medicinal or mystical/religious purposes (as medicine and spirituality are intertwined in Guarani worldview) and chose to use the term mystical/religious to refer to plants used in the treatment of illnesses of the spirit or in magical contexts, such as spells and magic (ka'avo), according to the traditional healing practices, also supported by Guarani bibliography (27).

\section{Material And Methods}

\section{Study area}

Seven Mbyá Guarani Indigenous Lands in the Atlantic Forest of southern Brazil were included in this research. They were chosen by convenience due to pre-existing contacts of the first author and the indication of propagule exchanges among them. The Atlantic Forest is a hotspot for biodiversity conservation (39), and the Guarani villages included in this study are in different phytophysiognomies (sensu of Instituto Brasileiro de Geografia e Estatística (IBGE) (40)): Dense Ombrophylous Forest, Seasonal Semideciduous Forest, and one village is located in an ecotone (transition zone) between the Dense Ombrophylous Forest and the Mixed Ombrophylous Forest.

The Indigenous Lands and their Tekoá (villages) are: 1) Nhuu Porã (also known as Campo Molhado, with 2268 ha, created in 2001) is located in the municipalities of Riozinho, Maquiné, and Caraá (Rio Grande do Sul state). Altitude ranges from 850 to $900 \mathrm{~m}$, and the village is in an ecotone area between Dense Ombrophylous Forest and Mixed Ombrophylous Forest in medium to advanced stages of regeneration 
due to the former logging exploration. The village is approximately $30 \mathrm{~km}$ from the urban environment, and the population is 25-30 people, distributed in five to six families. 2) Ka'aguy Porã (Retomada Indigenous Land, with $367 \mathrm{ha}$ ) is a territory occupied in 2017 located in the municipality of Maquiné (for details of this process, see Printes and Benites (24)). The region is of Dense Ombrophylous Forest, and the population is approximately 12 families (3). Yvy Poty (Flor da Terra Indigenous Land, acquired in 2014, with 100 ha) is located in the municipality of Barra do Ribeiro, near the city of Porto Alegre, and is within an area of Seasonal Semideciduous Forest. There are approximately 40 people in 12 families. 4) Anhetenguá (Lomba do Pinheiro Indigenous Land, created in 2012 with 25 ha) is located within the urban area of Porto Alegre, where approximately 16 families live. The vegetation is mostly composed of Pinus sp., with seasonal semideciduous forest fragments. 5) Jatai'ty (Cantagalo Indigenous Land, created in 2007 is the oldest in Indigenous Land in Rio Grande do Sul, with 283.67 ha) is located in Viamão municipality, in the metropolitan region of Porto Alegre. The vegetation is comprised of seasonal semideciduous forest and areas with Pinus sp. Currently, there are approximately 52 families. 6) Itaty and Yakã Porã (both villages are located in the Morro dos Cavalos Indigenous Land, declared in 2008 with $1,998 \mathrm{ha}$ ) is in the municipality of Palhoça, Santa Catarina state and is one of the oldest Guarani references in Santa Catarina (41). The vegetation is of Dense Ombrophylous Forest, and a protected area, the Serra do Tabuleiro State Park, overlaps the indigenous territory. Currently, 30 families live in Tekoá Itaty, and 7 families live in Yakã Porã. 7) Yyn Moroti Verá (M'Biguaçu Indigenous Land, approved in 2003 with $59 \mathrm{ha}$ ) is located in the municipality of Biguaçu, with forest cover of Dense Ombrophylous Forest and currently 44 families.

\section{Data collection}

Data were collected between October 2017 and November 2018. The maximum length of stay in one village was one week, but in two villages, the visit was only one day; however, the arrangements to visit each village took longer times. The length of stay in each village depended on the availability of the people to be interviewed. All interviews and moments of participant observation were preceded by obtaining prior consent from village leaders through agreement with a Prior Informed Consent Form, in compliance with the ethical precepts of ethnobiological research of the International Society for Ethnobiology Code of Ethics (42). The research was registered in the Ethics Committee of Universidade Federal de Santa Catarina - UFSC (73329517.0.0000.0121), the application for authorization to enter Indigenous Land was registered in the National Indian Foundation (FUNAI) (08620.000440/2018-17), and the register for associated traditional knowledge access in the National System for the Management of Genetic Heritage and Associated Traditional Knowledge (SISGEN) is under number A315C86. The authorization for collection of botanical material is registered by the number 6120635 in the Brazilian Biodiversity Authorization and Information System (SISBIO).

Data were collected through participant observation (43), semi-structured interviews (44) with key participants from each indigenous land, botanical collection and identification of the plants mentioned in the interviews. We used a non-probabilistic sampling for the interviews, including adults (over 18 years) who were the most involved with medicinal and mystical or religious use of plants, teachers, political or 
spiritual leaders, and those who usually participate in plant exchanges. We also respected social status within the villages, and we interviewed a maximum of five people in each village, also considering the optimization of time and resources available for the study (45). The semi-structured interviews had two parts: the first referred to the cultural and social characteristics that encourage or do not encourage the exchange of plants and to the person's perception of the environment, including the use of plants in traditional ceremonies, if she/he often visits other villages, if he/she was kinship related to people from the visited villages, and how important the forest environments are (full interview protocols are available upon request). The second part of the interview addressed the plants used for medicinal, mystical or religious purposes, whether they are native or exotic in the village, as well as which plants were exchanged and with which villages these exchanges occurred.

Plant collection was conducted according to Ming (46), and we had the support of botanical experts for the identification of vegetative material. Fertile vouchers were deposited in the UFSC FLOR Herbarium under numbers 66299 to 66319 and 67486 to 67487 . For plants whose collection was not possible, we made photographic records to check the possible botanical identification.

\section{Data organization and analysis}

Data were analyzed qualitatively and by calculating percentages of responses. Parts of the responses of the interviewees were transcribed, and those speeches inserted in the results were identified by the interviewee number, followed by the name of the Tekoá and Indigenous Land. Due to the different number of interviewees per village, the analysis of plant exchanges considered each village as a sampling unit. The exchanges made between the villages were analyzed through a bipartite network, in which we relate the visited villages with the villages that were mentioned in the plant exchanges. We used the package bipartite of the R platform Rx64 3.4.1 (47). We analyzed the origins and destinations of the interchanged plants to observe the movements between phytophysiognomies and the Guarani contributions to the ecological configurations of the vegetation and the selection of species.

We analyzed the influence of kinship on plant exchanges through four pre-established kinship categories: (1) absent (no kinship with anyone who exchanged plants, whether brought to the village or taken to another village), (2) very close (plants were exchanged with close relatives living in other villages: mother, father, children, grandparents, siblings), (3) close (plants were exchanged with uncles, cousins, or nephews of other villages), and (4) distant (plant exchanges with brother-in-law, sister-in-law, mother-inlaw, father-in-law, living in other villages).

Reported medicinal plant applications were separated into use categories according to the worldwide standard for disease classification of World Health Organization (WHO) (48). The idea of using this classification is not to standardize the traditional uses of plants, which go far beyond the WHO (48) classification, but to show the medicinal contexts in which plants are being applied and exchanged (49). We also considered that due to the context of use, some plants do not have a discrete distinction between medicinal and mystical or ritualistic. 


\section{Results}

Twelve key interviewees participated in the research: four women and eight men (five people at Cantagalo, two at Morro dos Cavalos, and one person in each of the other Indigenous Lands). Five interviewees needed the help of a Portuguese-Guarani translator. The other interviews were conducted in Portuguese because the interviewees were both Guarani and Portuguese speakers. Their ages varied from 30 to 69 years. The interviewees were chiefs, leaders, teachers, and people who said that they did not have a specific social position within the villages but who were indicated by the leaderships to participate in the research. Often, during the conversations, other people were present, sharing their knowledge about plant uses. Respecting the social context, we did not exclude them at these moments.

These key interviewees reported the use of 49 plant species of 27 botanical families (Table 1), and more than $87 \%$ of these species are native. The most representative family was Asteraceae with 6 species, followed by Myrtaceae and Fabaceae with 5 species each. The highest number of citations was for Jacaranda micrantha and Tabernaemontana catharinensis, each mentioned in three different villages. Four species were cited in two different villages: Schinus terebinthifolius, Luehea divaricata, Cabralea canjerana, and Petiveria alliacea. The other species were mentioned in only one village. Thus, there were 58 total citations of the 49 plants. 
Table 1

List of species reported in 12 interviews in Mbya Guarani villages in southern Brazil.

Family/Species $\begin{aligned} & \text { Guarani Portuguese name Uses Quotes/village } \\ & \text { name }\end{aligned}$

\section{Amaranthaceae}

Chenopodium sp.*

Ka’a ré

ME $\quad 1$

Anacardiaceae

Schinus terebinthifolius

Raddi*

Yrywajá

Aroeira mansa; pimenta

ME 2

Raddi*

orembiu

rosa

\section{Apocynaceae}

Tabernaemontana

catharinensis A. DC.*

Pipi guaxu

Jasmim-cata-vento;

forquilinha

ME 3

MR

\section{Aquifoliaceae}

Ilex paraguariensis A. St. -Hil.* Ka'a

Erva-mate

ME 1

MR

Araceae

Philodendron bipinnatifidum $\quad$ Ywaimbé $\quad$ Guaimbé; cipó-imbé $\quad$ ME 1

Schott ex Endl.*

Asteraceae

Achyrocline satureioides

(Lam.) DC.*

Ipoty ju va'e Macela

ME 1

Baccharis trinervis (Lam.)

Japecanga

ME 1

Pers.*

Calea pinnatifida (R. Br) Less* Yxiporó

Cipó-flor-de-maria-mole, jasmim-do-mato, quebratudo

Lepidaploa balansae (Chodat) H.Rob.*

Gajuruguay Tatatai

ME 1

Matricaria chamomila L.

Camomila

ME 1

Vernonanthura

tweedieana (Baker) H. Rob.*

Mata-campo

ME 1

Begoniaceae

Begonia cucullata Will.*

Araku ka'a

Azedinha do brejo

ME

1

Bignoniaceae

Legend: Uses: ME = Medicinal; MR = Mystical/ritualistic. ${ }^{*}=$ Native species 


\begin{tabular}{|c|c|c|c|c|}
\hline Family/Species & $\begin{array}{l}\text { Guarani } \\
\text { name }\end{array}$ & Portuguese name & Uses & Quotes/village \\
\hline Dolichandra sp.* & - & Unha-de-gato & $\begin{array}{l}\text { ME } \\
\text { MR }\end{array}$ & 1 \\
\hline Jacaranda micrantha Cham.* & Para paray & Caroba & ME & 3 \\
\hline \multicolumn{5}{|l|}{ Boraginaceae } \\
\hline $\begin{array}{l}\text { Cordia americana (L.) } \\
\text { Gottshling \& J.E.Mill.* }\end{array}$ & Guajayvi & Guajuvira & $\begin{array}{l}\text { ME } \\
\text { MR }\end{array}$ & 1 \\
\hline $\begin{array}{l}\text { Cordia monosperma Roem. \& } \\
\text { Schult.* }\end{array}$ & - & Erva-baleeira & ME & 1 \\
\hline Varronia curassavica Jacq.* & - & Erva-baleeira & ME & 1 \\
\hline \multicolumn{5}{|l|}{ Bromeliaceae } \\
\hline $\begin{array}{l}\text { Vriesea platynema } \\
\text { Gaudichaud var. platynema* }\end{array}$ & - & - & ME & 1 \\
\hline \multicolumn{5}{|l|}{ Cactaceae } \\
\hline $\begin{array}{l}\text { Cereus hildmannianus } \\
\text { K.Schum.* }\end{array}$ & - & - & ME & 1 \\
\hline \multicolumn{5}{|l|}{ Celastraceae } \\
\hline $\begin{array}{l}\text { Maytenus cf. ilicifolia } \\
\text { (Schrad.) Planch.* }\end{array}$ & Yvyrá poju & Espinheira santa & $\begin{array}{l}\mathrm{ME} \\
\mathrm{MR}\end{array}$ & 1 \\
\hline \multicolumn{5}{|l|}{ Cucurbitaceae } \\
\hline Cayaponia cf. palmata Cogn.* & - & Tayuya & $\begin{array}{l}\text { ME } \\
\text { MR }\end{array}$ & 1 \\
\hline \multicolumn{5}{|l|}{ Dioscoreaceae } \\
\hline Dioscorea sp.* & - & Salsaparrilha & ME & 1 \\
\hline \multicolumn{5}{|l|}{ Euphorbiaceae } \\
\hline $\begin{array}{l}\text { Euphorbia pulcherrima Willd. } \\
\text { ex Klotzsch }\end{array}$ & - & $\begin{array}{l}\text { Estrela de natal; bico de } \\
\text { papagaio }\end{array}$ & ME & 1 \\
\hline $\begin{array}{l}\text { Sapium glandulosum (L.) } \\
\text { Morong* }\end{array}$ & Kurupika'y & Pau-leiteiro & ME & 1 \\
\hline \multicolumn{5}{|l|}{ Fabaceae } \\
\hline Cajanus cf. indicus Spreng. & - & Feijão-guandú & ME & 1 \\
\hline Inga virescens Benth.* & Inga & Ingá & ME & 1 \\
\hline
\end{tabular}

Legend: Uses: $\mathrm{ME}=$ Medicinal; $\mathrm{MR}=$ Mystical/ritualistic. ${ }^{*}=$ Native species 


\begin{tabular}{|c|c|c|c|c|}
\hline Family/Species & $\begin{array}{l}\text { Guarani } \\
\text { name }\end{array}$ & Portuguese name & Uses & Quotes/village \\
\hline $\begin{array}{l}\text { Lonchocarpus cf. cultratus } \\
\text { (Vell.) Azevedo-Tozzi \& } \\
\text { H.C.Lima* }\end{array}$ & Yvyrá kati & Rabo-de-bugiu & ME & 1 \\
\hline $\begin{array}{l}\text { Machaerium stipitatum (D.C.) } \\
\text { Vogel** }\end{array}$ & Ixapy'y & Farinha-seca & ME & 1 \\
\hline $\begin{array}{l}\text { Zollernia ilicifolia (Brongn.) } \\
\text { Vogel** }^{*}\end{array}$ & Yvyra karai & $\begin{array}{l}\text { Falsa espinheira-santa; } \\
\text { fura-olho; carapicica-de- } \\
\text { folha-lisa }\end{array}$ & ME & 1 \\
\hline \multicolumn{5}{|l|}{ Gesnericaceae } \\
\hline $\begin{array}{l}\text { Sinningia douglasii (Lindl.) } \\
\text { Chautems* }^{*}\end{array}$ & - & Bata das árvores & ME & 1 \\
\hline \multicolumn{5}{|l|}{ Lamiaceae } \\
\hline $\begin{array}{l}\text { Plectranthus cf. barbatus } \\
\text { Andr. }\end{array}$ & $\begin{array}{l}\text { Teeraxy } \\
\text { poã }\end{array}$ & Boldo brasileiro & ME & 1 \\
\hline \multicolumn{5}{|l|}{ Lauraceae } \\
\hline $\begin{array}{l}\text { Cryptocarya aschersoniana } \\
\text { Mez* }^{*}\end{array}$ & - & Canela-fogo & ME & 1 \\
\hline \multicolumn{5}{|l|}{ Malvaceae } \\
\hline $\begin{array}{l}\text { Luehea divaricata Mart. \& } \\
\text { Zucc.* }\end{array}$ & Yxonguy & Açoita cavalo & ME & 2 \\
\hline Sida rhombifolia L.* & - & Guanxuma & ME & 1 \\
\hline \multicolumn{5}{|l|}{ Meliaceae } \\
\hline $\begin{array}{l}\text { Cabralea canjerana (Vell.) } \\
\text { Mart.* }\end{array}$ & Cansarana & Canjerana & ME & 2 \\
\hline Cedrela fissilis Vell.* & Yary & Cedro rosa & $\begin{array}{l}\text { ME } \\
\text { MR }\end{array}$ & 1 \\
\hline \multicolumn{5}{|l|}{ Myrtaceae } \\
\hline Eugenia uniflora L.* & $\begin{array}{l}\text { Nhanga } \\
\text { pity }\end{array}$ & Pitangueira & ME & 1 \\
\hline $\begin{array}{l}\text { Myrciaria floribunda (West ex } \\
\text { Willd.) O. Berg* }\end{array}$ & - & Cambuíva & ME & 1 \\
\hline $\begin{array}{l}\text { Plinia peruviana (Poir.) } \\
\text { Govaerts* }\end{array}$ & Ywapuru & Jaboticabeira & ME & 1 \\
\hline
\end{tabular}

Legend: Uses: $\mathrm{ME}=$ Medicinal; $\mathrm{MR}=$ Mystical $/$ ritualistic. ${ }^{*}=$ Native species 


\begin{tabular}{|c|c|c|c|c|}
\hline Family/Species & $\begin{array}{l}\text { Guarani } \\
\text { name }\end{array}$ & Portuguese name & Uses & Quotes/village \\
\hline $\begin{array}{l}\text { Plinia rivularis (Cambess.) } \\
\text { Rotman* }\end{array}$ & Guaporoity & Guapuriti & ME & 1 \\
\hline Psidium guajava L. & $\begin{array}{l}\text { Araxa } \\
\text { guaxu }\end{array}$ & Goiaba & ME & 1 \\
\hline \multicolumn{5}{|l|}{ Phitolacaceae } \\
\hline Petiveria alliacea L.* & Pipi & Guiné & ME & 2 \\
\hline \multicolumn{5}{|l|}{ Polygalaceae } \\
\hline Polygala paniculata L.* & - & $\begin{array}{l}\text { Gelol/Timutu-barba-de- } \\
\text { são-Pedro }\end{array}$ & $\begin{array}{l}\text { ME } \\
\text { MR }\end{array}$ & 1 \\
\hline \multicolumn{5}{|l|}{ Rosaceae } \\
\hline Prunus myrtifolia (L.) Urb.* & Yvaró & Pessegueiro do mato & MR & 1 \\
\hline Prunus persica $\mathrm{L}$. & - & Pêssego & ME & 1 \\
\hline \multicolumn{5}{|l|}{ Solanaceae } \\
\hline Physalis pubescens L.* & $\begin{array}{l}\text { Membyraxy } \\
\text { poã }\end{array}$ & Camapu & ME & 1 \\
\hline Solanum americanum Mill.* & Ka’a teí & $\begin{array}{l}\text { Erva-moura; maria } \\
\text { pretinha }\end{array}$ & ME & 1 \\
\hline Solanum mauritianum Scop.* & Kavaxinguy & Cavatinga & ME & 1 \\
\hline \multicolumn{5}{|l|}{ Urticaceae } \\
\hline Urera baccifera (L.) Sand.* & Pyno & Urtiga vermelha & ME & 1 \\
\hline
\end{tabular}

\section{Plant exchanges and therapeutic uses}

The interviewees of the seven villages exchanged plants with 19 villages in the states of Rio Grande do Sul, Santa Catarina, and the province of Misiones in Argentina (Figs. 1 and 2). Of the 58 plant citations (including repeated citations), propagules were exchanged for $46 \%$ of these plants ( 27 plants), summing 33 exchanges. Some plants were exchanged more than once; for example, Zollernia ilicifolia was received by one village and was supplied to three other villages, accounting for four exchanges. No exchanges were reported by the interviewees at Retomada and Lomba do Pinheiro, although these villages were indicated in other villages as suppliers or recipients of propagules. For this reason, these two villages were not included in the column of visited villages of the bipartite network (Fig. 2). 
The reasons for the visits include the search for seeds and medicines, visiting relatives, political articulations, knowledge exchange, the strengthening of themselves and of the Guarani culture, helping each other, and the well-being associated with travels and visits.

We found a greater number of exchanges between villages whose interviewees have close relatives, corresponding to 17 exchanges. In contrast, there were 10 exchanges between villages in which the interviewees were not kinship related. Four exchanges occurred between villages with very close kinship, and two exchanges occurred between villages with distant kinship (Fig. 3). Therefore, villages where kinship was considered close or very close made $64 \%$ of the reported exchanges.

According to interviewee \#1 (Tekoá Ka'aguy Porã, Retomada), "when visiting relatives, the place is always observed, if it is good for children, if it is healthy". During these visits, seedlings of medicinal plants and medicine knowledge are also exchanged. Interviewee \#2 (Tekoá Jatai'ty, Cantagalo) said that most exchanges take place with plants ready to use, such as the barks or leaves; when the seeds or seedlings are available, they are exchanged, but this does not guarantee that the propagule will be established in the other village because the environments can be very different. In Tekoá Nhuu Porã (Campo Molhado), interviewee \#3 also pointed out that plants are not necessarily exchanged through the mediation of a giver: if the person who visits another village knows which plant is needed, he/she just brings it. Most of the plants received in exchanges are incorporated in the families' homegardens, amongst other species brought directly from the nearby forests, becoming easily accessible when needed.

Seedlings or vegetative material transported between villages included especially native species, corresponding to $89 \%$ of the plants exchanged ( 24 species). Only three exotic species were exchanged: Matricaria chamomilla, Plectranthus cf. barbatus and Cajanus cf. indicus. Among the exchanged plants, Tabernaemontana catharinensis was the most cited. Some older exchanges were reported at Morro dos Cavalos, but with the precise origin of the plants unknown, as some Plinia peruviana trees brought from Argentina, probably in the 1960s. At least one individual of Campomanesia sp. and seedlings of Ilex paraguariensis were also brought in the past to this village.

Medicinal use was exclusive to $74 \%$ of the exchanged plants (20 species), $22 \%$ (6 species) were used for both medicinal and mystical uses, and one was used for mystic uses only (4\%, Tabernaemontana catharinensis). For example, for interviewee \#3, mate (Ilex paraguariensis) has both uses, and their relationship with this plant is related to great wealth, to protect the soul, and to talk among souls. Most plants were cultivated (67\%) and $33 \%$ spontaneous. Trees comprise $52 \%$ of the exchanges, herbs $22 \%$, shrubs $15 \%$, and vines $11 \%$.

Exchanged medicinal plants are mainly used to treat blood and circulatory system (3), cuts, scars and skin (6), problems in the joints (1), cancer (1) digestive diseases (5), respiratory (5), genitourinary (3), and feminine cycles (5), contemplating vital functions of the organism, in addition to the mystical and religious uses, of spiritual importance. Some plants have more than one therapeutic function. For example, according to the chief of Cantagalo, some plants are used to take care of physical and other spiritual diseases. For him, jurua (non-indigenous) medicines are used to treat physical issues, but for 
spiritual illness, only the Karai (spiritual leadership) knows how to solve the illnesses through traditional medicine. Guarani establish complex relationships with the plants depending on the person and the plant, and many physical and spiritual diseases are not split into different categories. For interviewee \#4 (Tekoá Yakã Porã, Morro dos Cavalos), "The medicinal herb for the Guarani people is sacred, it is not just an herb, a bush, or a leaf, it is a spirit, a brother of ours, who helps in healing, who helps in liberation. So for us the medicinal herbs are very sacred". For interviewee \#3, "Those who work with medicines have to know well which plant to use. There are many remedies, but plants are specific to each thing. There are two types of Yxonguy, for example, and each has a different application. To be accurate at the time of diagnosis, you need to talk well with the person to know the history of the disease".

A remarkable topic related to medicinal plant uses is women's illnesses. According to interviewee \#5 (Tekoá Itaty, Morro dos Cavalos), there are a number of recommendations during the woman's gestation period, which should be followed by both parents. These include using plants to maintain the well-being of children and parents. In addition to chamomile, other plants appear in the exchange list whose application is intended for women's health, such as Jacaranda micrantha, Physalis pubescens, Schinus terebinthifolius, and Plinia rivularis. On one of the visits to Tekoá Nhuu Porã, we observed the dissatisfaction of one mother who reported that her daughter had to give birth in a hospital, and traditional methods involving herbs could not be performed.

\section{Mbyá Guarani Eco-cultural health and the forest environments}

Some species have been described as essential for conducting ceremonies at Opy (ceremonial house). The presence of the Opy in each tekoá is central. The Opy is a space for meetings and sharing, for ceremonies, chants, dances, healings, and for the relations with other beings and deities, expressing Guarani sociocosmology. Within the Opy, plants play an essential role, in which plant and forest properties are incorporated. The use of native plants is a priority in ceremonies, including those used to light the sacred fire, such as Holocalyx balansae and Cedrela fissilis. C. fissilis is also used in objects such as the apyka for the baptism of children, in baths or infusions, together with ka'a (llex paraguariensis), and with the herbs that will be used and strengthened in prayers. According to interviewee \#6 (Tekoá Yakã Porã, Morro dos Cavalos), "Opy is connected with all nature, the plants used are preferably native". Guarani white corn (Zea mays) is central, as well as ka'á and pety (Nicotiana tabacum), to open the concentration, to have spirit, and to maintain the culture. Pipi (Petiveria alliacea) is used to strengthen the body and mind and in baths for cleaning, as well as yvaró (Prunus brasiliensis), and to receive spirits well. Many plants used traditionally have magical value, but this information is not widely shared.

The role and strength of ceremonies and prayers in healing and plant use procedures are highlighted by interviewee \#7 (Tekoá Jatai'ty, Cantagalo): “Learning comes through praying, getting to know medicine and culture, listening to spirituality"; and M.B., from the same village: "When a patient is going to be 
treated at the opy, the karai feel the necessary medicines that will be strengthened along with praying to improve the patient, especially spiritual illnesses".

The Guarani healing context is intrinsically related to the forest. For interviewee \#8 (Tekoá Jatai'ty, Cantagalo), "We are children of nature, she provides what is necessary to live in it, the elderly always say, it shows the way of how to live". For interviewee \#9 (Tekoá Yvy Poty, Flor da Terra), "Every indigenous person knows that without nature, they have no conditions, the land strengthens life, and with a lot of forest they have everything: food, health, education, knowledge and guarantees culture". The responses on perceptions regarding the presence and importance of the woods and forests revealed key concepts such as health (66\%), culture (25\%), joy (16\%), life (16\%), food (16\%), balance (8\%), education ( $8 \%$ ) and knowledge (8\%). The presence of forests and rivers is what allows the culture and way of being Guarani to be experienced, taking into account the ecological and cosmological aspects in the Guarani concept for good living, such as direct contact with deities and sacred food.

Thus, food also acts as a medicine. Interviewee \#5 also stressed the purification that the ancients perform through food and good habits. For her, "It [the forest] has everything necessary, health, food, air and good water, it is the balance for life. It allows direct contact with the deities and keeps the energy strong to receive new lives. Forest foods are sacred for this".

The presence of forests is directly related to both individual and community good health. Interviewee \#3 reinforced the Guarani cosmological view, with the central relationship between health, plants, and forest: "Our body is just like the earth, that's why nature heals us. This is the medicine of the Indian. All plants act on the health of the planet itself and maintain the health of all beings. The fruits fall to the ground and feed the animals and the land itself. God placed the plants for the Guarani to use. A fruit is like medicine; when we eat it, we are healing. This is about health, Nhanderú guides our way, whenever we ask from the heart. [...]. Many jurua say that the Guarani are losing knowledge of the plants, but the Guarani know that the most valuable plants have been cut. Barks have been used since childhood, and a tree has never died, it still lives 100, 200 years and the person thus has protection".

The disappearance of the forests and the demarcation of territories were also mentioned, since every indigenous person keeps the ancestral territory in their memory, and for some of them, the idea of limiting a space to live becomes almost incomprehensible. For interviewee \#3, "The native forest no longer exists, it was cut too much to feed ships, trains and other things that juruá invented for his work, and that today is the very death of many people [...] The Indian's pharmacy is the forest, but many medicines were cut. Today, if an Indian wants to take some medicine, or fish, he often cannot because the land or the river now has an "owner"." Many poã (remedies from the forest) are no longer found within the limited indigenous land, and searching for certain plants that are outside the demarcated territories incurs a risk of being mistaken for a criminal act. According to Interviewee \#9 (Tekoá Yyn Moroti Vherá, MBiguaçu), "The territory is not restricted to the demarcated area, now many plants are found outside the area".

At Campo Molhado indigenous land, which is located in an ecotone, the chief reported the presence of a total of 24 plant species brought to the village that can be currently found only in the forests of Misiones 
in Argentina. In other villages, the lack or rarity of some important species in traditional medicine include plants such as Ipe (Handroanthus sp.) trees in Lomba do Pinheiro and Mbiguaçu, and katiguá (Trichilia sp.) and cipó-guembé (probably Philodendron bipinnatifidum) at Retomada. Up to the time of this study, three of the seven villages had seedling nurseries for reforestation of native species of traditional importance.

\section{Discussion}

\section{The influence of Guarani plant exchange networks on Atlantic Forest composition}

In the Guarani cosmology, the natural world is closely connected with the supernatural world, which often occupies the same spaces $(27,50)$. Within this cosmology, the maintenance of botanical knowledge with therapeutic functions is also important (51), as well as the exchanges among villages. As we hypothesized, the connections between the villages through family and kinship ties facilitate plant exchange networks across the Guarani traditional territory. Our results reveal a small snapshot of the current panorama of the networks that connect the Guarani villages and the exchanges of plants that are still taking place in the Atlantic Forest biome, with emphasis on native species. A caveat of our study is that this snapshot is also limited by our small sample of villages and interviewees in each village, which were guided by Guarani's availability and by their own indications of who we should interview.

In the exchange network, Tekoá Nhuu Porã (Campo Molhado), Tekoá Yyn Moroti Vherá (Mbiguaçu) and Tekoá Jatai'ty (Cantagalo) stand out with more citations and connections with the other villages mentioned (Figs. 1 and 2). These villages are located closer to the coast, and the plant exchanges revealed links with villages that are in the west part of Rio Grande so Sul and Santa Catarina States, as well as with the region of Misiones, in Argentina, more than $900 \mathrm{~km}$ from the Atlantic coast. In those areas, the Alto Uruguai Deciduous Seasonal Forest formations predominate, and the Indigenous Lands keep valuable forest fragments amidst monocultures. In Argentina, there are greater extensions of forest cover. One of these areas is the Yabotí Biosphere Reserve (52), a region identified by the Guarani as a place of reference to find certain floristic elements. Exchanges between these western villages and the Atlantic coast were already observed (27), with the transportation of propagules such as Chrysophyllum gonocarpum, Luehea divaricata, Parapiptadaenia rigida, Holocalyx balansae, and Petiveria alliaceae to the village of Mbiguaçu.

Almost half of the plants exchanged were trees, followed by herbs. Heineberg and Hanazaki (35) observed similar results among the Laklãnõ-Xokleng (from Jê linguistic group), reinforcing the importance of knowledge about forest tree species of indigenous peoples. In the present study, these plants associated with exchanges have the potential to be incorporated in environments and phytophysionogmies different than those of the place of origin. 
For example, among the Myrtaceae family - one of the most important in the Atlantic Forest, with several edible fruit species (28) - Plinia rivularis was mentioned as an exchanged plant. It was brought from a place with Deciduous Seasonal Forest of upper Uruguay to Flor do Campo village, where the phytophysiognomy is of Semideciduous Forest. The origin of the individual of Plinia peruviana mentioned in Cantagalo is unknown since it was cultivated by a former resident. According to Sobral et al. (53), this species is characteristic of the Seasonal Semideciduous Forest and Mixed Ombrophylous Forest, which are forest formations different from the forest at Cantagalo. The dominance of this family in the Atlantic Forest may be related to the management carried out by indigenous peoples in the past, including, for example, enriched areas with Myrtaceae fruit trees in the South region found between the 19th and 20th centuries (28).

Several exchanged plants are related to religious beliefs. Keller, Prance, Tressens, Duarte (51), citing Cadogan (12), highlighted the complexity of Mbyá Guarani medicine plants related to religious beliefs. Seven exchanged plants were in this category. Among them, Tabernaemontana catharinensis stands out for its importance in the spiritual context. In the two villages of Rio Grande do Sul state, the seedlings of this species were brought from a village at São Miguel das Missões, Tekoá Koendju. The occurrence of this species is attributed to the whole Atlantic forest region $(53,54)$, but for the interviewees, it is rare, and the individuals present in the studied villages come from the exchanges. In M'Biguaçu, all individuals of T. catharinensis were planted, brought in the 1980s, but of unknown origin.

Yerba mate, or ka'a, Ilex paraguariensis, is a species exchanged with cultural and medicinal value for Guarani $(55,56)$. A variety of yerba mate with a lighter shade on the leaves were brought from Misiones to Campo Molhado indigenous land, and it is different from the one already found there, showing the potential of exchanges to increase the local variability of the species. Individuals of this species are also present in Morro dos Cavalos indigenous land, at Ombrophyllous Dense forest, which is not the attributed distribution for this species (usually occurring above $400 \mathrm{~m}$ of altitude (57)). This is another example of the transport of plants of cultural value to phytophysiognomies other than those of original occurrence. The historical relationship of yerba mate with indigenous peoples is not restricted to the Guarani: the species was also consumed among peoples of the Chaco and the Andes, where it does not occur spontaneously (56). The name "mate" is even derived from the Quechua word "mati", which means the gourd or porongo where the drink is traditionally consumed. This leads us to an interethnic network of relationships in which people probably exchanged and cultivated the plant (56). Oliveira and Esselin (56), based on Posey (58), fit the plant in the category of semidomesticated because they are intentionally managed. If this management had not already taken place by the natives, it would have been more difficult to expand the herbs for economic exploitation, as occurred in the 19th century (56).

Another highly esteemed species is Cedrela fissilis, yary, which is considered a medicine of sacred value $(1,16,51)$. It is a well-distributed species in South America and is one of the most threatened tree species, with a vulnerable status (54) due to the selective cutting and suppression of the Atlantic Forest. Given its cultural importance, it is likely that the Guarani historically contributed to the dispersion of this species through their exchanges. 
Petiveria alliacea is another example of the Guarani influence on species composition in the southern Atlantic Forest. At Cantagalo, it was brought from the nearby village of Lami. Galante (1), Keller, Prance, Tressens, Duarte (51) and Bueno et al. (59) mentioned the traditional use of the species by the MbyáGuarani of Misiones (Argentina), the Kaiowá and Guarani of Mato Grosso do Sul, and the Guarani of São Paulo, respectively. This plant is also used by other indigenous groups, such as the Ka'apor of Maranhão, also from the Tupi group (60). The origin of this species is probably the Amazon rainforest (57).

Solanum mauritianum and Urera baccifera have a wide distribution both in the Atlantic Forest and in other Brazilian biomes, respectively (54). Both species were brought from the deciduous to semideciduous forest at Cantagalo and are mentioned in other studies with the Guarani $(1,16,27)$, showing once again that the Guarani exchanges may have contributed historically to the composition of different phytophysiognomies.

Some species are naturally occurring in the phytophysiognomies of indigenous lands; however, they can be locally rare or absent. For example, Philodendron bipinnatifidum is one of the plants that are named at Opy, so that their ja (owner) authorizes their use (1). It is native to all forest formations in southeastern Brazil (57). However, in Morro dos Cavalos, there was only one known individual, a fact that also motivated the exchanges. The whip horse, Luehea divaricata, is another important species in Guarani medicine (27). The species is present in the cerrado and in all formations of the Atlantic forest (53). Despite this, in Campo Molhado, it was reported as not available spontaneously, which motivated the exchange. Oliveira (27) reported the absence of the plant in Mbiguaçu and the request of people from this village to purchase seedlings for planting.

Guarani exchanges can also contribute to the distribution of non-native plants. Three species exchanged were probably introduced in Brazil in the colonial period (57). These plants were also recorded in studies by Oliveira (27) for Plectranthus barbatus among the Guarani of Mbiguaçu, Noelli (18) for Matricaria chamomilla and Cossio (16) for Cajanus indicus.

Additionally, the exchanges of parts of plants with no propagative potential, such as for Inga virescens taken from Campo Molhado to a village in the Pampa biome, reflect the distribution of knowledge and the broad spectrum that the relationship Guarani-plants reach. This species is related to altitude forests, being better distributed in the Mixed Rain Forest (61) and absent in Pampa.

Oliveira (27) discussed possible migratory routes that contributed to the transport of species of flora from seasonal forests from the interior of the South American continent to the Atlantic coast. Klein (62) elaborated a list with species that would be characteristic of these routes, some of them mentioned in our study: Para paray - Jacaranda micrantha, Yxonguy - Luehea divaricata and Pipi - Petiveria aliacea (27). According to Reitz and Klein (63), factors such as climatic fluctuations could have favored seasonal forests so that certain species could reach the Atlantic coast, but Oliveira (27) states that the routes proposed by Klein overlap with the archeological sites of Guarani presence in southern Brazil, where many villages are also present today (27). 


\section{Guarani family, extended family}

We found that more than half of the plant exchanges occurred between villages whose interviewees had close relatives, but there were also exchanges between villages with no close kinship ties. The caveat here is that our categorization of kinship relations oversimplifies the Guarani concept of extended family. The concept of extended family is "the most widespread sociological model" in Amerindian social organizations $(22,64)$. For Guarani, this organization is composed of several nuclear families (women and men who live together and their children) united by kinship and affinity relationships. Thus, an extended Guarani family can be made up of the wife (or a group of sisters) and her husband, the daughters married to their sons-in-law, unmarried children, and their daughters' children. In these bonds, the "blood" relatives are called retarã, affinity relatives are the towadjá, and the aggregates also recognized as relatives by the bonds with the host family are the guapepó. The extended family can include many domestic groups spread over several villages $(20,22)$.

The Guarani understand the non-indigenous concepts of kinship (e.g., brothers, cousins, uncles, grandparents), and thus, we chose to maintain these distinctions in data collection without disregarding the existence of a context in which the family is extended. Thus, the relations between the relatives considered to be close and very close keep the exchanges active, although the nature of the non-related by kinship needs to be broadened under the perspective of extended families.

Being on the move is a way for the individual to maintain health and happiness (25). In this sphere, the sense of being in the Guarani world is added, such as the search for Yvy Marã'ey, the Land without Evils, and the mborayu, or reciprocity $(20,50)$. These elements favor the exchange of plants between people and villages, which end up circulating in different phytophysiognomies while strengthening social bonds, kinship, and affinity relationships (22).

\section{Teko porã, well-being, and eco-cultural health}

Within their extended territory, all tekoá (Guarani villages) are connected and, through their geographical distribution, represent the support and structure of the Mbyá world (65). Religiosity permeates the Guarani daily life, and Opy holds the position of the social, political, religious and educational center of the village $(21,22,25)$. Ceremonies are usually mediated by karaí or opygua (spiritual leaders, shamans, prayers), who know how to receive and interpret divine words and have knowledge about healing and traditional remedies $(5,21,22,27,66)$.

For the well-being and maintenance of Guarani customary practices, forest environments are essential, which permeate the reasons for migration in search of a good place to settle. Forest environments provide the essentials for health and happiness, good water and land, a source of food and medicines and direct contact with deities. Taking care of rivers, land, and forests is part of the individual and collective health that involves not only humans but also those who share these spaces in the natural and supernatural worlds, and these environments must be maintained for those that will come later because so did the ancestors $(50,67)$. 
Although historically the Guarani have occupied the lower lands of the Atlantic Forest (68), in the archaeological record, there are Guarani sites in the three southern states of Brazil in the area of mixed rain forest and forest transition areas (10). Villages present in transition areas of phytophysiognomies (as shown in Fig. 1) can contribute to the Guarani interaction with a diversity of species and emphasize the effects of indigenous management of the Atlantic Forest landscape (see also Pereira Cruz et al. (30)). For Guarani people, dreams and visions of older people often guide decisions when considering places to live, relating the natural environments to the cosmology of the Guarani way of life $(27,67)$, highlighting their understanding of an intrinsic relationship between well-being and forests.

There are essential plants used in rituals that the Guarani seek to maintain. The small spaces in which indigenous lands are located, especially in southern Brazil, impose challenges to access and collect plants, such as orchids at indigenous lands near Porto Alegre and at Morro dos Cavalos (69), and medicinal plants (66). The interest in the presence of plants intended for women's health demonstrates, for example, the concern of communities to take care of everything that involves women's cycles and is also a way of maintaining traditional practices amidst social and environmental changes, without relying on medical assistance from juruá kuery $(70,71)$. Noelli $(18)$ emphasizes in this sense the flexibility and structure of the Guarani medical system, which over the past centuries has sought the efficacy of both native and introduced plants to combat the entire arsenal of previously unknown diseases to which they were subjected, such as influenza, smallpox, measles, malaria, typhus, yellow fever, venereal diseases, and tuberculosis.

Historically, the Guarani have demonstrated their flexibility in dealing with the natural resources they have, in parallel with their sociocultural unity. The search for the necessary conditions for well-being and the understanding of eco-cultural health with an intrinsic link between health and forest also support the process of domestication of the landscape $(72,73)$. Historical and continuous interactions with forests maintain important elements in the environment for cultural continuity in a healthy and safe way. Plant exchanges and the management of certain species can also provide information about possible domestication processes that may occur at different levels $(27,28,30)$ and contribute to the continuous genesis of cultural landscapes of Atlantic forests.

\section{Conclusions}

Almost half of the plants reported were involved in some exchange between villages, which marks an intense movement of plants in the Atlantic Forest to strengthen health and culture and enrich the forest environments. In this sense, the Guarani are enriching their territories with species related to their traditional pharmacopoeia, both for physical and spiritual health. This process is related to the traditional mobility inherent to the Guarani people, also with contributions of the partnerships that have been established between the villages and educational institutions, the civil community, and the creation and maintenance of nurseries in the villages. We observed through this flow of plants and knowledge the real capacity of species to be incorporated in phytophysiognomies different from those in which they are usually described, such as, for example, the species characteristic of the Seasonal Semideciduous and 
Mixed Ombrophyllous forests taken to Ombrophyllous Dense forest. For Pereira, Noelli, Campos, Santos, Zocche (28), the Guarani contribution to the ecological configurations of these environments, such as favoring some species, is still an open topic for study, which brings us to millennia of human influence in the Neotropics. Currently, indigeneity in landscapes (72) is being registered and mapped, as territorial management plans have been developed in indigenous lands, adapting traditional botanical and ecological knowledge to contemporary reality.

The presence of indigenous communities, through the conscious management of the territory, helps to maintain species of ecological and cultural importance (29), sometimes threatened, being extremely important for the conservation of the biodiversity of the Atlantic Forest. This also opens the debate about what is native and exotic in the Guarani conception, especially when considering the scope of the original Guarani territory and the historical human interaction with the environments. Many species have been managed and transported in the past, and as we have seen, it is a process that is constantly ongoing. The plants that are migrating among very different phytophysiognomies, associated with human action, are related to the historical management and selection of important species that characterize landscape transformations, in addition to the natural adaptation processes that plants develop. The various purposes in which biodiversity is used reflect Mbyá's own mobility, whose expression of their way of being also happens through territoriality (24).

Recognizing and valuing Guarani knowledge and practices can help restore and conserve natural environments, as well as collaborate for health in a broader way of understanding, as well as develop more sustainable economic and management practices, in addition to providing a better understanding of occupation of the Atlantic Forest in its southern portion. These ideas have been developed in places such as Colombia and Suriname by the Amazon Conservation Team (ACT) (74) and among the peoples of the Rio Negro in the northwestern Amazon, for example (75). Encouraging public policies related to biodiversity and traditional peoples is instituted in the Convention on Biological Diversity (76), as well as in the Global Strategy for the Conservation of Plants (76), even though we are far from effectively achieving this goal (77).

The Atlantic Forest is a sacred and ancestral territory of immense cultural and environmental value to the world. It is essential to implement public policies that contemplate the safeguarding of these spaces, with the real participation of the people who live in it for longer timespans, such as the Guarani people.

\section{Declarations}

\section{Ethics approval and consent to participate}

The research was registered in the Ethics Committee of Universidade Federal de Santa Catarina - UFSC (73329517.0.0000.0121), the application for authorization to enter Indigenous Land was registered in the National Indian Foundation (FUNAI) (08620.000440/2018-17), and the register for associated traditional knowledge access in the National System for the Management of Genetic Heritage and Associated 
Traditional Knowledge (SISGEN) is under number A315C86. The authorization for collection of botanical material is registered by the number 6120635 in the Brazilian Biodiversity Authorization and Information System (SISBIO).

\section{Consent for publication}

All interviews and moments of participant observation were preceded by obtaining prior consent from village leaders through agreement with a Prior Informed Consent Form, in compliance with the ethical precepts of ethnobiological research of the International Society for Ethnobiology Code of Ethics (42). All the authors and participants of present research agreed in publish this manuscript in present form.

\section{Availability of data and materials}

The data used to support the findings of this study are available from the corresponding author upon reasonable request.

\section{Competing interests}

The authors have no competing interests to declare.

\section{Funding}

This study was financed in part by the Coordenação de Aperfeiçoamento de Pessoal de Nível Superior Brasil (CAPES) - Finance Code 001. NH thanks to CNPQ for a research productivity scholarship.

\section{Authors' contributions}

Conceived of the presented idea: JHCA, NH

Carried out the experiment: JHCA, JR, AB, CB, AA, MB, CB, IG, JVS, EA, EA, JM, DMT, SF, JCPM

Carried out the data analysis: JHCA, FRS, NH

Wrote the first draft of the manuscript: JHCA, NH

Review and final write of the manuscript: JHCA, EA, FRS, NH

Supervision: $\mathrm{NH}$ 


\section{Acknowledgements}

Sincere thanks to all Guarani communities and interviewees who participated in the work, to the Laboratory of Human Ecology and Ethnobotany, to the Department of Botany, Herbarium FLOR, to the Graduate Program in Biology of Fungi, Algae and Plants at UFSC, to P. Fiaschi, A. N. Silva, F. S. Cabral and M. Grings who helped to identify plant species.

\section{References}

1. Galante L. Investigação etnobotânica na comunidade Guarani Mbya de Tekoa Pyau [masters dissertation]. [São Paulo, SP]: Pontifícia Universidade Católica de São Paulo; 2011. 161p.

2. Haverroth M. Etnobotânica, uso e classificação dos vegetais pelos Kaingang - Terra Indígena Xapecó. 1st. ed. Recife: NUPEEA/ Sociedade Brasileira de Etnobiologia e Etnoecologia; 2007.

3. Instituto Socioambiental. Povos indígenas no Brasil 2011-2016. 1st. ed. São Paulo: ISA; 2016.

4. Felipim AP. O sistema agrícola Guarani Mbyá e seus cultivares de milho: um estudo de caso na Aldeia Guarani da Ilha do Cardoso, município de Cananéia, SP [masters dissertation]. [São Paulo, SP]: Universidade Estadual de São Paulo; 2001. 120 p.

5. Oliveira D. Arandu nhembo'ea: cosmologia, agricultura e xamanismo entre os Guarani-chiripá no litoral de Santa Catarina [masters dissertation]. [Florianópolis]: Universidade Federal de Santa Catarina; 2011. 283 p.

6. Corrêa AG. Pindorama de Mboia e lakaré: continuidade e mudança na trajetória das populações Tupi [PhD thesis]. [São Paulo, SP]: Universidade de São Paulo; 2014. 462 p.

7. Kreutz MR, Santos PD, Machado NG, Laroque LF. A colonização Guarani nas Planícies do Taquari, Rio Grande do Sul. Brasil Tellus. 2014. doi:10.20435/tellus.v0i27.320.

8. Milheira RG. Arqueologia Guarani na laguna dos Patos e na Serra do Sudeste. 1st. ed. Pelotas: Editora UFPel; 2014.

9. Noelli FS. La distribuición geográfica de las evidencias arqueológicas Guaraní. Rev Indias. 2004. doi:10.3989/revindias.2004.i230.408.

10. Schneider F, Wolf S, Kreutz MR, Machado NTG. Tempo e Espaço Guarani: Um estudo acerca da ocupação, cronologia e dinâmica de movimentação pré-colonial na Bacia do Rio Taquari/Antas, Rio Grande do Sul, Brasil. Bol Mus Para Emílio Goeldi Ciênc hum. 2017.

doi:10.1590/1981.81222017000100003.

11. Brighenti CA. Estrangeiros na própria terra: Presença Guarani e Estados Nacionais. 1st. ed. Florianópolis/Chapecó: Editora da UFSC/Argos; 2017.

12. Cadogan L. Sintesis de La Medicina Racional y Mística Mbyá-guarani. Am Ind. 1949;9:21-36.

13. Noelli FS. Aportes históricos e etnológicos para o reconhecimento da classificação Guarani de comunidades vegetais no século XVII. Fronteiras: Revista de História. 1998a;2:275-96. 
14. Pissolato E. Mobilidade, multilocalidade, organização social e cosmologia: a experiência de grupos Mbya-Guarani no sudeste brasileiro. Tellus. 2004;6:65-78.

15. Schaden E. Aspectos Fundamentais da Cultura Guarani. 3rd. ed. São Paulo: Epu/ Edusp; 1974.

16. Cossio RR. Etnoecologia, caminhante, oguata va'e, em trilhas para descolonização de relações interculturais: circulação de pessoas e plantas Mbya Guarani entre Brasil e Argentina [masters dissertation]. [Porto Alegre]: Universidade Federal do Rio Grande do Sul; 2015. 221 p.

17. Brochado JP. A expansão dos Tupi e da cerâmica da tradição policrômica amazônica. Dédalo. 1989;27:65-82.

18. Noelli FS. Múltiplos usos de espécies vegetais pela farmacologia Guarani através de informações históricas. Diálogos. 1998b;2:177-99.

19. Rogge JH. Adaptação na floresta subtropical: a tradição Tupiguarani no Médio Rio Jacuí e no Rio Pardo. Arqueologia do Rio Grande do Sul, Documentos. 1996;6:3-156.

20. Assis VS. Dádiva, mercadoria e pessoa: as trocas na constituição do mundo social Guarani [masters dissertation]. [Porto Alegre]: Universidade Federal do Rio Grande do Sul; 2006. 326 p.

21. Baptista MM. O Mbyá Reko (Modo de Ser Guarani) e as Políticas Públicas na Região Metropolitana de Porto Alegre: uma discussão sobre o Etnodesenvolvimento [masters dissertation]. [Porto Alegre]: Universidade Federal do Rio Grande do Sul; 2011. 170 p.

22. Mello FC. Aetchá Nhanderukuery Karai Retarã. Entre Deuses e Animais: Xamanismo, Parentesco e transformação entre os Chiripá e Mbyá [PhD thesis]. [Florianópolis]: Universidade Federal de Santa Catarina; 2006. 298 p.

23. Berkes F. Sacred Ecology. 4th. ed. London/ New York: Routledge; 2018.

24. Printes RB, Benites A. Retomada no Yvy Rupá. Resistência Mbya Guarani em terras ancestrais no litoral do Rio Grande do Sul. In: ENCONTTRA, Coletivo de Estudos sobre Conflitos pelo Território e pela Terra, editors. Anais do VIII Simpósio Internacional de Geografia Agrária and IX Simpósio Nacional Geografia Agrária. ENCONTTRA; 2017; Curitiba. Curitiba: ENCONTTRA; 2017.

25. Soares MA. Espaço ritual e bem viver guarani: reflexões sobre uma política pública no sul do Brasil. lluminuras. 2015. doi:10.22456/1984-1191.61246.

26. Ciccarone $\mathrm{C}$. Um povo que caminha: notas sobre movimentações territoriais guarani em tempos históricos e neocoloniais. Dimensões. 2011;26:136-51.

27. Oliveira D. Nhanderukueri ka'aguy rupa: as florestas que pertencem aos deuses: etnobotânica e territorialidade Guarani na terra indígena M'biguaçu/SC [undergraduate dissertation]. [Florianópolis]: Universidade Federal de Santa Catarina; 2009. 182 p.

28. Pereira GS, Noelli FS, Campos JB, Santos MP, Zocche JJ. Ecologia Histórica Guarani: As Plantas Utilizadas no Bioma Mata Atlântica Do Litoral Sul De Santa Catarina, Brasil (Parte 1). Cadernos do LEPAARQ. 2016;8:198-246.

29. Levis C, Costa FR, Bongers F, Peña-Claros M, Clement CR, Junqueira AB, Neves EG, Tamanaha EK, Figueiredo FO, Salomão RP, Castilho CV. Persistent effects of pre-Columbian plant domestication on 
Amazonian forest composition. Science. 2017. doi:10.1126/science.aal0157.

30. Pereira Cruz A, Giehl EL, Levis C, Machado JS, Bueno L, Peroni N. Pre-colonial Amerindian legacies in forest composition of southern Brazil. PLoS One. 2020. doi:10.1371/journal.pone.0235819.

31. Posey DA. Indigenous knowledge, biodiversity, and international rights: learning about forests from the Kayapó Indians of the Brazilian Amazon. Commonwealth Forest Rev. 1997;76:53-60.

32. Votre GC, Noelli FS, Pereira G, de S, Pavei, Zocche DD, Santos JJ, CAMPOS MCP JB. Arqueologia entre rios: do Urussanga ao Mampituba - Arqueobotânica Guarani. In: UNESC, editors. Anais da VIII Semana de Ciência e Tecnologia; 2017; Criciúma, SC, Brasil. Criciúma, SC, Brasil: UNESC; 2017. p. $123-42$.

33. Crovetto R. Introducción a la etnobotánica aborigen del nordeste argentino. Etnobiologica. 1968. doi:10.30972/etn.0112360.

34. Díaz-Reviriego I, González-Segura L, Fernández-Llamazares Á, Howard PL, Molina JL, Reyes-García V. Social organization influences the exchange and species richness of medicinal plants in amazonian homegardens. Ecol Soc. 2016. doi:10.5751/ES-07944-210101.

35. Heineberg MR, Hanazaki N. Dynamics of the botanical knowledge of the Laklãnõ-Xokleng indigenous people in Southern Brazil. Act Bot Bras. 2019. doi:10.1590/0102-33062018abb0307.

36. Hopkins A. Use of network centrality measures to explain individual levels of herbal remedy cultural competence among the Yucatec Maya in Tabi, Mexico. Field Method. 2011. doi:10.1177/1525822X11399400.

37. Lope-Alzina DG. Una red comunal de acceso a alimentos: el huerto familiar como principal proveedor de productos para intercambio en una comunidad Maya-Yucateca. Gaia Sci. 2014;8:199-215.

38. Coomes OT, Mcguire SJ, Garine E, Caillon S, McKey D, Demeulenaere E, Jarvis D, Aistara G, Barnaud A, Clouvel P, Emperaire L, Louagi S, Martin P, Massol F, Pautasso M, Violon C, Wencélius J. Farmer seed networks make a limited contribution to agriculture? Four common misconceptions. Food Pol. 2015. doi:10.1016/j.foodpol.2015.07.008.

39. Silva Filho PJS, Silva CC, Franco FP, Cavalli J, Bertholdo LM, Schmitt LA, Ilha R, Mondin CA. Levantamento florístico de um fragmento de Floresta Ombrófila Densa no litoral norte do Rio Grande do Sul, Brasil. R Bra Bio. 2013;11:163-83.

40. Instituto Brasileiro de Geografia e Estatística. Manual técnico da vegetação brasileira. 1st. ed. Rio de Janeiro: IBGE; 1992.

41. Litaiff A, Darella MDP. Os índios Guarani/Mbya e o Parque Estadual da Serra do Tabuleiro. In: Associação, Brasileira de Antropologia, editors. Anais eletrônicos da XXII Reunião Brasileira de Antropologia. Fórum de Pesquisa 3: Conflitos Socioambientais e Unidades de Conservação; 2000; Brasília. Brasília, DF, Brasil: Associação Brasileira de Antropologia; 2000.

42. International Society of Ethnobiology. International Society of Ethnobiology Code of Ethics (with 2008 additions). 2006. http://ethnobiology.net/code-ofethics//. Accessed 24 July 2018.

43. Bernard HR. Research methods in anthropology: qualitative and quantitative approaches. 2 nd. ed. Walnut Creek: AltaMira Press; 1995. 
44. Albuquerque UP, Lucena FPR, Alencar LN. Métodos e Técnicas para coleta de dados etnobiológicos. In: Albuquerque UP, Lucena RFP, Cunha LVFC, editors. Métodos e Técnicas na pesquisa Etnobiológica e Etnoecológica. 1st. ed. Recife: NUPEEA; 2010. pp. 41-63.

45. Tongco MDC. Purposive sampling as a tool for informant selection. Ethnobotany Res Appl. 2007;5:147-58.

46. Ming LC. Coleta de Plantas Medicinais. In: Di Stasi LC, editor. Plantas medicinais: arte e ciência. Um guia de estudo interdisciplinar. 1st. ed. São Paulo: Editora UNESP; 1996. pp. 47-68.

47. R Core Team. R: A language and environment for statistical computing. R Foundation for Statistical Computing. Vienna, Austria. 2018. https://www.R-project.org/. Accessed 18 Sept 2019.

48. World Health Organization. International statistical classification of diseases and related health problems (ICD-10). 2010. https://icd.who.int/ browse10/2016/en. Accessed 10 December 2018.

49. Zank S, Hanazaki N. The coexistence of traditional medicine and biomedicine: A study with local health experts in two Brazilian regions. PLoS One. 2017. doi:10.1371/journal.pone.0174731.

50. Melià BSJ. A Terra Sem Mal dos Guarani: Economia e profecia. Rev Antropol. 1990;33:33-46.

51. Keller H, Prance GT, Tressens SG, Duarte R. Ethnobotanical resources of multiple-use Guaraní Reserve, Misiones (Argentina): their importance to indigenous communities of Caramelito and Taruma Poty-I. Ethnobotany. 2010;22:38-54.

52. Tressens SG, Keller HA, Revilla V. Las plantas vasculares de la reserva de uso múltiple Guaraní, Misiones (Argentina). B Soc Arg Bot. 2008;43:273-93.

53. Sobral M, Jarenkow JA, Brack P, Irgang B, Larocca J, Rodrigues RS. Flora arbórea e arborescente do Rio Grande do Sul, Brasil. 1st. ed. São Carlos: RiMa/Novo Ambiente; 2006.

54. Jardim Botânico do Rio de Janeiro. Flora do Brasil 2020 under development. 2019. http://floradobrasil.jbri.gov.br/. Accessed 28 May 2019.

55. Contini AZ, Castilho MA, Brito R. A erva-mate e os Kaiowá e Guarani: da abordagem etnobotânica à promoção do desenvolvimento local. Interações (Campo Grande). 2012. doi:10.1590/S151870122012000200003.

56. Oliveira JE, Esselin PM. Uma breve história (indígena) da erva-mate na região platina: da Província do Guairá ao antigo sul de Mato Grosso. Espaço Ameríndio. 2015;9:278-318.

57. Lorenzi H, Matos FJA. Plantas Medicinais no Brasil: nativas e exóticas. 2nd. ed. Nova Odessa: Instituto Plantarum; 2008.

58. Posey DA. Introdução. Etnobiologia e prática. In: Ribeiro B, editor. Suma etnobiológica brasileira. Petrópolis: Vozes/FINEP; 1987. pp. 15-25.

59. Bueno NR, Castilho RO, Brito R, Pott A, Pott VJ, Scheidt GN, Batista MS. Medicinal plants used by the Kaiowá and Guarani indigenous populations in the Caarapó Reserve, Mato Grosso do Sul, Brazil. Act Bot Bras. 2005;19:39-44.

60. Balick MJ, Cox PA. Plants, people and culture: The Science of Ethnobotany. 1st. ed. New York: Scientific American Library; 1997. 
61. Possette RFS, Rodrigues WA. O gênero Inga Mill. (Leguminosae - Mimosoideae) no estado do Paraná, Brasil. Act Bot Bras. 2010. doi:10.1590/S0102-33062010000200006.

62. Klein RM. Ecologia da flora e vegetação do Vale do Itajaí. Sellowia. 1980;32:165-389.

63. Reitz R, Klein RM. O reino vegetal de Rio do Sul. Sellowia. 1964;16:9-118.

64. Santiago T. translator. A sociedade contra o estado. 1st. ed. São Paulo: Cosac \& Naify; 2003.

65. Heckler JM. Sementes e saberes... trocas e aprendizados com a cultura Guarani e a agroecologia [masters dissertation]. [Porto Alegre, RS]: Universidade Federal do Rio Grande do Sul; 2006. 134 p.

66. Litaiff A. O sistema médico Guarani. Re Ci Hum. 1996;14:107-15.

67. Pissolato E. A duração da pessoa: mobilidade, parentesco e xamanismo mbya (guarani). 1st. ed. São Paulo: Editora UNESP, ISA. Rio de Janeiro, RJ: NuTi; 2007.

68. Scatamacchia MCM. A Tradição Policrômica no Leste da América do Sul evidenciada pela ocupação Guarani e Tupinambá: fontes arqueológicas e etnohistóricas [PhD thesis]. [São Paulo, SP]: Universidade de São Paulo; 1990. 310 p.

69. Blanco GD. Estudo Etnobotânico e Morfoanatômico de espécies de Orchidaceae utilizadas por grupos Guarani [masters dissertation]. [Florianópolis]: Universidade Federal de Santa Catarina; 2017. $155 \mathrm{p}$.

70. Benites J. 0 direito à saúde pública para os Guarani: o caso da comunidade de Mymba Roka [undergraduate dissertation]. [Florianópolis]: Universidade Federal de Santa Catarina; 2015. 37 p.

71. Moreira A. Puru'a reko: A saúde na gestação e no parto da mulher Guarani [undergraduate dissertation]. [Florianópolis]: Universidade Federal de Santa Catarina; 2015. 43 p.

72. Balée W. Sobre a Indigeneidade das Paisagens. Rev Arq. 2008. doi:10.24885/sab.v21i2.248.

73. Clement CR, Denevan WM, Heckenberger MJ, Junqueira AB, Neves EG, Teixeira WG, Woods WI. The domestication of Amazonia before European conquest. P R Soc B - Biol Sci. 2015. doi:10.1098/rspb.2015.0813.

74. Amazon Conservation Team. The Amazon Conservation Team. https://www.amazonteam.org/ (2018). Accessed 25 July 2018.

75. Cabalzar A, Fonseca-Kruel VS, Martins L, Milliken W, Nesbitt M, editors Manual de etnobotânica: plantas, artefatos e conhecimentos indígenas. 1st. ed. São Paulo, SP: Instituto. Socioambiental, São Gabriel da Cachoeira, AM: Federação das Organizações Indígenas do Rio Negro (FOIRN); 2017. 83 p.

76. Secretariat of the Convention on Biological Diversity. Convention on Biological Diversity. https://www.cbd.int/ (2018). Accessed 11 July 2018.

77. Hanazaki N, Zank S, Fonseca-Kruel VS, Schmidt IB. Indigenous and traditional knowledge, sustainable harvest, and the long road ahead to reach the 2020 Global Strategy for Plant Conservation objectives. Rodriguesia. 2018. doi:10.1590/2175-7860201869409.

\section{Figures}




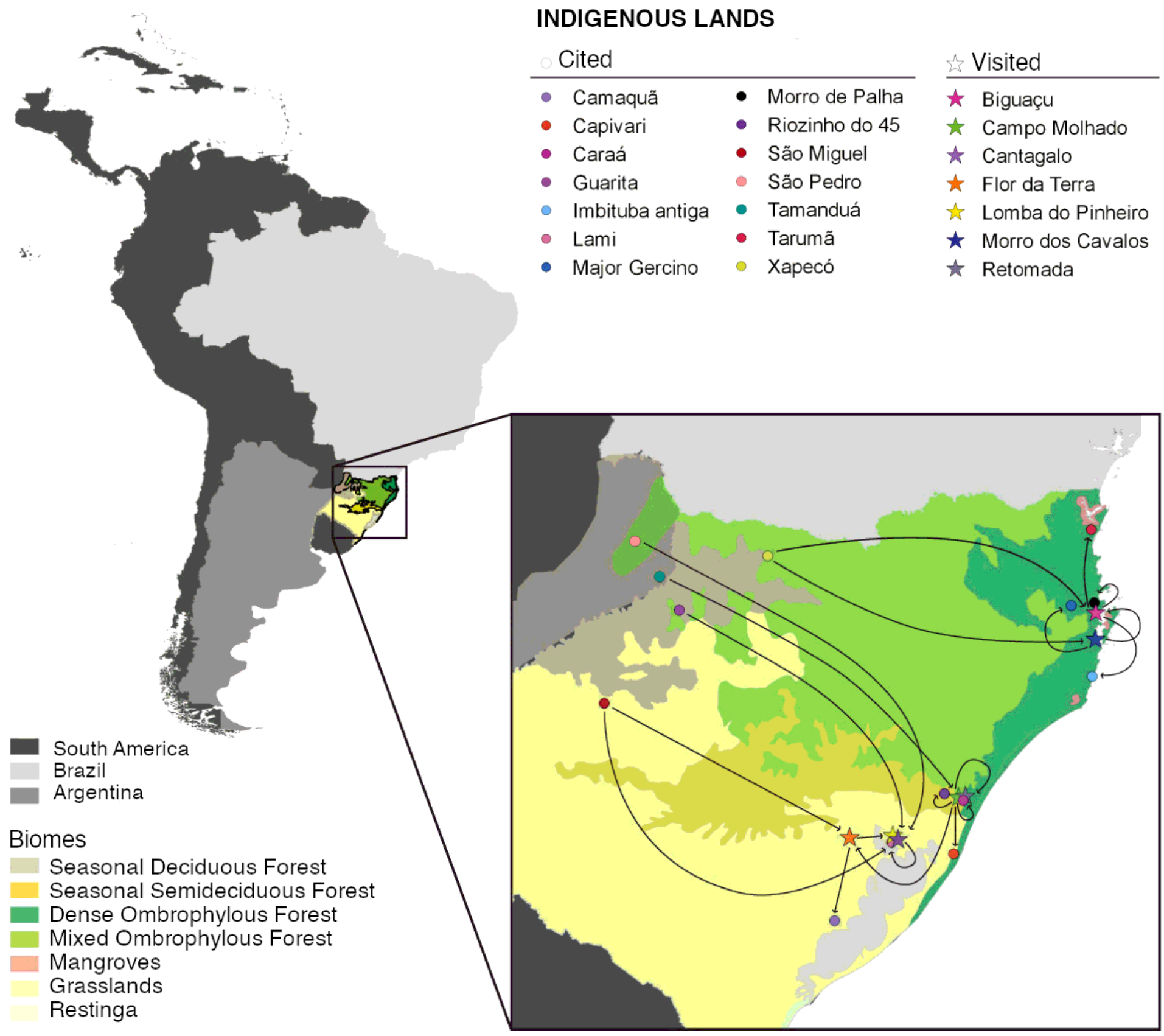

\section{Figure 1}

Location of the villages visited in the study (stars) and those with which were exchanges (circles), with the phytophysiognomies in which the villages are present. The arrows indicate the flow of propagules between villages. Note: The designations employed and the presentation of the material on this map do not imply the expression of any opinion whatsoever on the part of Research Square concerning the legal status of any country, territory, city or area or of its authorities, or concerning the delimitation of its frontiers or boundaries. This map has been provided by the authors. 


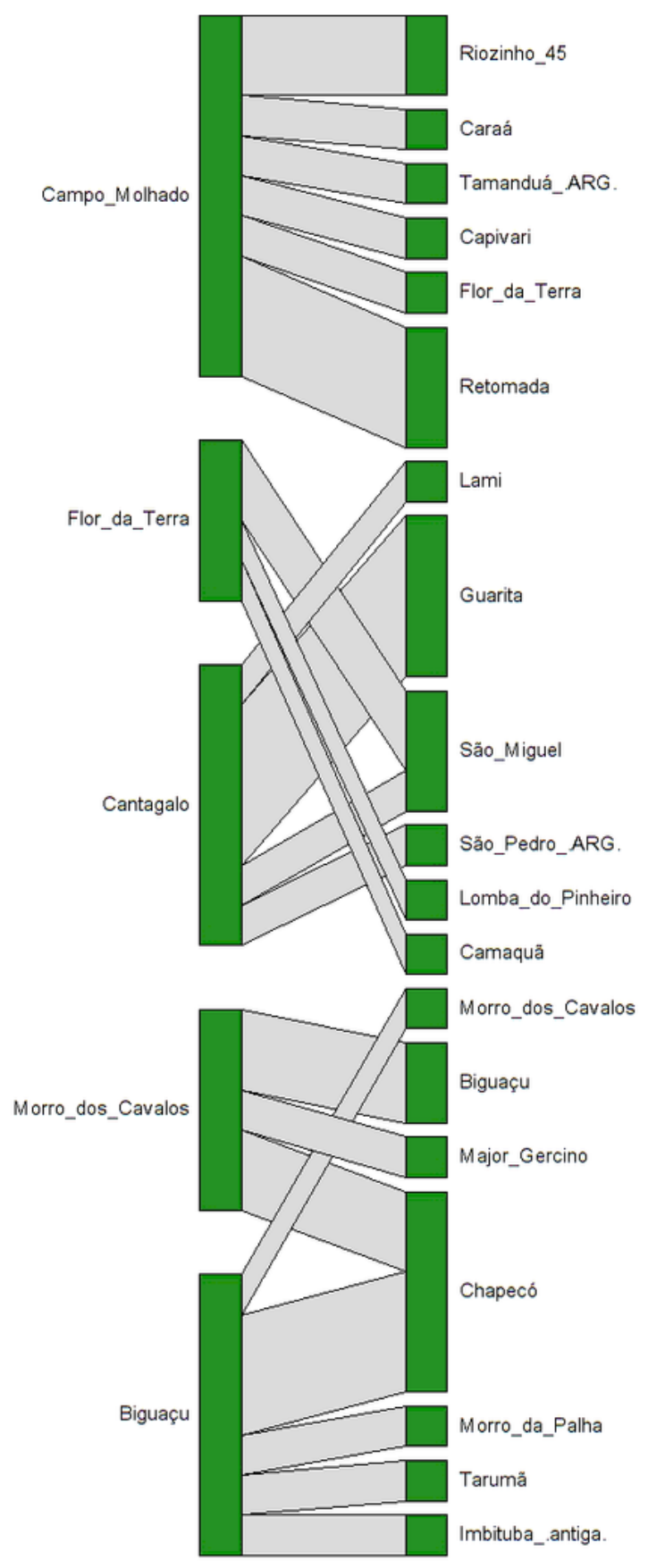

\section{Figure 2}

Bipartite network illustrating the exchange of propagules between Guarani villages, built from interviews in seven villages in Santa Catarina and Rio Grande do Sul. In the left column are the villages visited; on the right are the villages with which exchanges took place (ARG indicates that they are villages located in Argentina). The intensity of the connections determines the number of plant changes. 


\section{very close \\ $12 \%$}

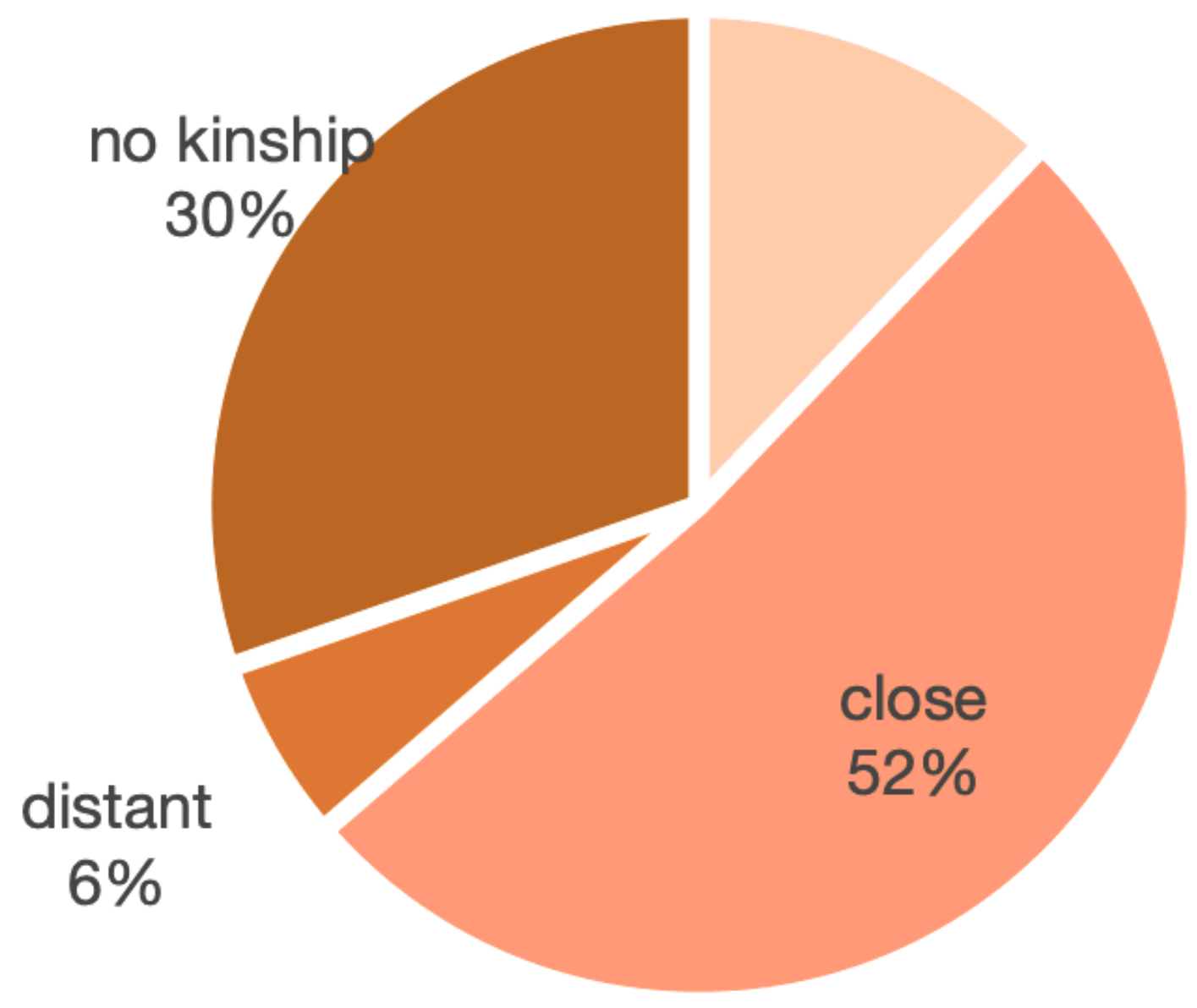

Figure 3

Percentage of exchanges and kinship relationships between villages, for 33 species of plants exchanged. 